\title{
Isolation of a virus infecting the novel shellfish- killing dinoflagellate Heterocapsa circularisquama
}

\author{
Kenji Tarutani, Keizo Nagasaki ${ }^{*}$, Shigeru Itakura, Mineo Yamaguchi \\ Harmful Algal Bloom Division, National Research Institute of Fisheries and Environment of Inland Sea, 2-17-5 Maruishi, \\ Ohno, Saeki, Hiroshima 739-0452, Japan
}

\begin{abstract}
A virus infecting the novel shellfish-killing dinoflagellate Heterocapsa circularisquama (H. circularisquama Virus: HcV) was isolated from Japanese coastal waters in August 1999 during a $H$. circularisquama bloom. Transmission electron microscopy of ultrathin sections of infected $H$. circularisquama revealed the presence of intracellular virus-like particles 24 to $48 \mathrm{~h}$ after infection. The virus was icosahedral, lacking a tail, ca 180 to $210 \mathrm{~nm}$ (mean \pm standard deviation $=197 \pm 8 \mathrm{~nm}$ ) in diameter and contained an electron-dense core. It was a double-stranded DNA virus, and the appearance of the virus particles was associated with a granular region (viroplasm) in the cytoplasm that did not appear within uninfected cells. The virus caused cell lysis of 18 strains of $H$. circularisquama isolated from various embayments throughout central and western Japan, but did not lyse 24 other phytoplankton species that were tested. To our knowledge, this is the first report of a virus infecting dinoflagellates which has been isolated and maintained in culture, and our results demonstrate that viruses which infect and cause lysis of dinoflagellates are a component of natural marine viral communities.
\end{abstract}

KEY WORDS: Dinoflagellate $\cdot$ Harmful algal bloom $\cdot \mathrm{HcV} \cdot$ Heterocapsa circularisquama $\cdot$ Viral infection Resale or republication not permitted without written consent of the publisher

\section{INTRODUCTION}

Heterocapsa circularisquama Horiguchi sp. nov. is a small thecate dinoflagellate (20 to $29 \mu \mathrm{m}$ in length, 14 to $20 \mu \mathrm{m}$ in width), which was recently described from Ago Bay, central Japan (Horiguchi 1995). Since this dinoflagellate was first recorded in Uranouchi Bay in the western part of Japan in 1988, its distribution area has expanded rapidly into embayments throughout central and western Japan (Matsuyama 1999). Due to such distribution expansion, this species has often formed large-scale red tides and caused mass mortality of bivalves such as pearl oysters Pinctada fucata, oysters Crassostrea gigas, and short-necked clams Tapes philippinarum (Matsuyama et al. 1996, Nagai et al. 1996, Matsuyama 1999). The most notable case occurred in 1998 when a large bloom resulted in severe financial losses of approximately 4 billion yen to

*Corresponding author. E-mail: nagasaki@nnf.affrc.go.jp the culture oyster industry in Hiroshima Bay (Matsuyama 1999). Due to the severe damage caused to commercial fisheries, there is an urgent need to find a way of predicting blooms and establishing preventative measures. As a result, several physiological and ecological studies have been conducted in order to clarify the mechanism of bloom outbreaks and toxicity of this species (Uchida et al. 1995, 1999, Matsuyama et al. 1996, Nagai et al. 1996, Yamaguchi et al. 1997).

Viruses or virus-like particles have been observed in numerous phytoplankton species from most major classes (Dodds 1979, Van Etten et al. 1991, Reisser 1993, Zingone 1995, Proctor 1997). These observations have led to increased interest in the role of algal viruses in aquatic environments. Some reports suggest that viruses are significant agents of phytoplankton mortality, and directly control the population dynamics of phytoplankton by viral lysis (Suttle et al. 1990, Bratbak et al. 1993, Nagasaki et al. 1994). Also, as a result of the release of cell contents due to viral lysis of the 
host organisms, viruses may indirectly affect the carbon and nutrient flow in natural aquatic ecosystems (Gobler et al. 1997, Thingstad \& Lignell 1997).

Despite the importance of the role of algal viruses in marine ecosystem, detailed information on the effect of viral infection on marine phytoplankton is still lacking. The main reason for this is that most studies have been based on ultrastructural observations of field-collected phytoplankton cells, while few algal host-virus systems have been successfully cultured and studied in the laboratory to date (Waters \& Chan 1982, Cottrell \& Suttle 1991, 1995, Van Etten et al. 1991, Suttle \& Chan 1995, Bratbak et al. 1996, Jacobsen et al. 1996, Nagasaki \& Yamaguchi 1997, Gastrich et al. 1998, Nagasaki et al. 1999a). In the present paper, we describe the isolation and general characteristics of a virus infecting and lysing Heterocapsa circularisquama. To our knowledge, this is the first report on a virus infecting a dinoflagellate which has been isolated and maintained in culture.

\section{MATERIALS AND METHODS}

Algal cultures and growth conditions. The main strains of Heterocapsa circularisquama, HU9433-P and HA92-1, used throughout this study were isolated from Uranouchi Bay (Kochi Prefecture, Japan) in 1994 and Ago Bay (Mie Prefecture, Japan) in 1992, respectively (Table 1). Both strains were extracellularly axenic, but

Table 1. List of Heterocapsa circularisquama strains used in this study and susceptibility of these strains against HcV03 infection. +: lysed

\begin{tabular}{|lllc|}
\hline Isolate & \multicolumn{2}{c}{ Isolation } & Susceptibility \\
& Locality & Date & \\
\hline AG978 & Ago Bay & Aug 1997 & + \\
HA92-1 & Ago Bay & Dec 1992 & + \\
HI9428 & Imari Bay & Sep 1994 & + \\
HK9903-1 & Hakata Bay & Mar 1999 & + \\
HK9903-2 & Hakata Bay & Mar 1999 & + \\
HK9903-3 & Hakata Bay & Mar 1999 & + \\
HK9903-8 & Hakata Bay & Mar 1999 & + \\
HO-2 & Obama Bay & Sep 1997 & + \\
HU9433 & Uranouchi Bay & Mar 1994 & + \\
HU9433-P & Uranouchi Bay & Mar 1994 & + \\
HY9423 & Yatsushiro Kai & Sep 1994 & + \\
MZ-1 & Maizuru Bay & Dec 1998 & + \\
MZ-2 & Maizuru Bay & Dec 1998 & + \\
MZ-3 & Maizuru Bay & Dec 1998 & + \\
MZ-4 & Maizuru Bay & Dec 1998 & + \\
MZ-5 & Maizuru Bay & Dec 1998 & + \\
UN979 & Unoshima Port & Sep 1997 & + \\
WK-2 & Wakinoura & Aug 1999 & + \\
& Fisheries Port & & \\
\hline
\end{tabular}

HA92-1 harbors bacteria within the cell probably in a symbiotic relationship. In contrast, HU9433-P was obtained by selecting a non-bacteria-harboring cell from the original strain isolated from Uranouchi Bay (HU9433), most of whose cells harbor some bacteria within them, and was thus intracellularly axenic. Other $H$. circularisquama strains used for host range study were isolated from various embayments throughout central and western Japan (Table 1). In addition, 24 algal species listed in Table 2 were also used as potential host organisms. All algal strains used in this study were maintained in the National Research Institute of Fisheries and Environment of Inland Sea, Japan. Cultures were grown in modified SWM3 medium (Chen et al. 1969) enriched with $2 \mathrm{nM} \mathrm{Na}_{2} \mathrm{SeO}_{3}$ under a 12:12 h light:dark cycle of ca $50 \mu \mathrm{mol}$ photons $\mathrm{m}^{-2} \mathrm{~s}^{-1}$ with cool white fluorescent illumination. All experiments were performed at $20^{\circ} \mathrm{C}$, with the exceptions of Alexandrium tamarense, Chaetoceros didymum, Chattonella verruculosa, Ditylum brightwellii, Skeletonema costatum and Thalassiosira sp., which were grown at $15^{\circ} \mathrm{C}$.

Virus isolation. A surface water sample was collected in a small fishing port (Wakinoura Fishing Port) in Fukuoka Prefecture, Japan, during a bloom of Heterocapsa circularisquama (11 August 1999) and sent to the laboratory within $24 \mathrm{~h}$ of sampling. This sample was gently filtered through a $0.2 \mu \mathrm{m}$ pore size polycarbonate membrane filter (Nuclepore). Aliquots (1 ml) of filtrate were inoculated into $1 \mathrm{ml}$ of exponentially growing $H$. circularisquama HA92-1 cultures and were incubated under the conditions described above. Control cultures were inoculated with the $0.2 \mu \mathrm{m}$ filtrate heat-treated at $100^{\circ} \mathrm{C}$ for $15 \mathrm{~min}$.

The clonal pathogen was obtained through 2 cycles of the extinction dilution procedure (Cottrell \& Suttle 1991, Nagasaki \& Yamaguchi 1997). Briefly, each culture lysate was diluted with modified SWM3 medium in a series of 10 -fold dilution steps. Aliquots $(100 \mu \mathrm{l})$ of each dilution were added to 8 wells in cell-culture plates with 96 round bottom wells (NUNC), mixed with $150 \mu \mathrm{l}$ of exponentially growing culture of Heterocapsa circularisquama HA92-1 strains, and incubated under the conditions described above. Lysed cultures were removed from the most diluted wells in which lysis occurred and the above entire procedure was repeated. The lysate in the most diluted wells of the second assay was sterilized by filtration through $0.2 \mu \mathrm{m}$ pore size polycarbonate membrane filters and transferred into an exponentially growing culture of $H$. circularisquama HU9433-P. The resultant lysate was centrifuged at $7000 \mathrm{rpm}(4490 \times g)$ for $2 \mathrm{~min}$ at $4^{\circ} \mathrm{C}$ to remove cell debris, and the supernatant was used as the clonal pathogen suspension.

Aliquots (5\% v/v) of the pathogen suspension were added to triplicate exponentially growing cultures of 
Table 2. List of phytoplankton strains used in this study and susceptibility of these strains against HcV03 infection. -: not lysed

\begin{tabular}{|c|c|c|c|}
\hline \multirow[t]{2}{*}{ Species (strain) } & \multicolumn{2}{|c|}{ Isolation } & \multirow[t]{2}{*}{ Susceptibility } \\
\hline & Locality & Date & \\
\hline \multicolumn{4}{|l|}{ DINOPHYCEAE } \\
\hline Alexandrium catenella (UJm) & \multicolumn{2}{|c|}{ Uwajima Bay (sediments) } & _- \\
\hline Alexandrium tamarense (KR-6) & Kure Bay & Apr 1998 & - \\
\hline Gymnodinium catenatum (1ax) & Inokushi Bay & Apr 1996 & - \\
\hline Gymnodinium mikimotoi (G303-ax2) & Suo Nada & Jul 1985 & - \\
\hline Gymnodinium sanguineum (UR974) & Uranouchi Bay & Apr 1997 & - \\
\hline Heterocapsa triquetra (H9104) & Hiroshima Bay & Apr 1991 & - \\
\hline Prorocentrum micans (8304) & Hiroshima Bay & Jul 1983 & - \\
\hline Prorocentrum triestinum (H9109) & Hiroshima Bay & Sep 1991 & - \\
\hline Scrippsiella trochoidea (KR) & Kure Bay & Apr 1997 & - \\
\hline \multicolumn{4}{|l|}{ BACILLARIOPHYCEAE } \\
\hline Chaetoceros didymum (Ch-4) & Hiroshima Bay & Mar 1989 & - \\
\hline Ditylum brightwellii (Di) & Hiroshima Bay & Mar 1989 & - \\
\hline Skeletonema costatum (SK-1) & Hiroshima Bay & Mar 1989 & - \\
\hline Thalassiosira sp. (Th-2) & Hiroshima Bay & Feb 1989 & - \\
\hline \multicolumn{4}{|l|}{ CHLOROPHYCEAE } \\
\hline Oltmannsiellopsis viridis & Osaka Bay & Oct 1993 & - \\
\hline \multicolumn{4}{|l|}{ CRYPTOPHYCEAE } \\
\hline Rhodomonas ovalis & Off Fukuyama & Jun 1967 & - \\
\hline \multicolumn{4}{|l|}{ EUGLENOPHYCEAE } \\
\hline Eutreptiella sp. (Eut-ax01) & \multicolumn{2}{|c|}{ Hiroshima Bay (sediments) } & - \\
\hline \multicolumn{4}{|l|}{ EUSTIGMATOPHYCEAE } \\
\hline Nannnochloropsis sp. (SFBB) & \multicolumn{2}{|l|}{ Unknown } & - \\
\hline \multicolumn{4}{|l|}{ PRYMNESIOPHYCEAE } \\
\hline Isochrysis galbana & \multicolumn{2}{|l|}{ Unknown } & - \\
\hline Pavlova lutheri & Unknown & & - \\
\hline \multicolumn{4}{|l|}{ RAPHIDOPHYCEAE } \\
\hline Chattonella antiqua (HBG8) & \multicolumn{2}{|c|}{ Hiuchi Nada (sediments) } & - \\
\hline Chattonella marina (UR976) & Uranouchi Bay & Jun 1997 & - \\
\hline Chattonella verruculosa (Misuji) & Hiroshima Bay & May 1993 & - \\
\hline Fibrocapsa japonica (Fib-1) & Harima Nada & Oct 1985 & - \\
\hline Heterosigma akashiwo (H93616) & Hiroshima Bay & Jun 1993 & - \\
\hline
\end{tabular}

Heterocapsa circularisquama HU9433-P. Control cultures received no addition. Growth of $H$. circularisquama was monitored as in vivo chlorophyll fluorescence using a Turner Designs fluorometer (Brand et al. 1981). Serial transfers of lysed culture to triplicate exponentially growing cultures of $H$. circularisquama were performed twice to propagate any pathogen that was present. Moreover, the pathogen suspension was also tested for infectivity following filtration through $0.1 \mu \mathrm{m}$ (Anotop ${ }^{\mathrm{TM}} 25$, Anotec) and $0.2 \mu \mathrm{m}$ pore size filters (DISMIC-25, Advantec) or treatment at $100^{\circ} \mathrm{C}$ for 15 min.

Transmission electron microscopy. Duplicate Heterocapsa circularisquama HU9433-P cultures were inoculated with $5 \%(\mathrm{v} / \mathrm{v})$ of clonal pathogen suspension. Control cultures received no addition. Subsamples were withdrawn at 0,24 , and $48 \mathrm{~h}$, fixed with $1 \%$ glutaraldehyde, and harvested by centrifugation $\left(2000 \mathrm{rpm}[860 \times \mathrm{g}], 10 \mathrm{~min}, 4^{\circ} \mathrm{C}\right)$. The cell pellets were post-fixed for $3 \mathrm{~h}$ in $2 \%$ osmic acid (in $0.1 \mathrm{M}$ phosphate buffer, pH 7.2 to 7.4 ), dehydrated in a graded ethanol series, and embedded in Quetol 653 resin (NISSHIN EM Co., Ltd). Thin sections were stained with $4 \%$ uranyl acetate, $3 \%$ lead citrate, and observed at $80 \mathrm{kV}$ using a JEOL JEM-1010 transmission electron microscope.

The suspension was absorbed onto carbon-coated copper grids, stained with $4 \%$ uranyl acetate, and observed at $80 \mathrm{kV}$ using a JEOL JEM-1010 transmission electron microscope. Particle diameters were estimated from negatively stained images.

Epifluorescence microscopy. The clonal pathogen was also observed using epifluorescence microscopy following staining with DAPI (4', 6-diamidino-2-phenylindole) as described in Suttle (1993) and Weinbauer \& Suttle (1997). Briefly, the clonal pathogen suspension was fixed with glutaraldehyde at a final concentration of $1 \%$, and DAPI solution was added to each fixed sample at a final concentration of $1 \mu \mathrm{g} \mathrm{ml} \mathrm{m}^{-1}$. The stained samples were filtered onto $0.02 \mu \mathrm{m}$ pore size Anodisk filters (Whatman) under a low vacuum. The filters were mounted on a glass slide with a drop of 
low-fluorescence immersion oil and covered with another drop of immersion oil and a cover slip. The slides were viewed at a magnification of $1000 \times$ with an Olympus BX50 epifluorescence microscope.

Viral DNA extraction and restriction enzyme analysis. An aliquot $(2 \% \mathrm{v} / \mathrm{v})$ of fresh viral suspension was added to a $900 \mathrm{ml}$ culture of exponentially growing Heterocapsa circularisquama HU9433-P. After 5 d the lysed culture was prefiltered through a glass fiber filter (Whatman GF/F). The viruses were collected from the filtered lysate by centrifuging at $22000 \mathrm{rpm}$ (56800 and $85900 \times g$, respectively) for $50 \mathrm{~min}$ in a P42A-974 rotor (Hitachi) and $\mathrm{P} 40 \mathrm{ST}-1400$ rotor (Hitachi).

The viral DNA was extracted almost according to the procedure of Maniatis et al. (1982). Briefly, the resultant pellet was treated with Proteinase K $\left(100 \mu \mathrm{g} \mathrm{ml}^{-1}\right)$ in $0.15 \mathrm{M} \mathrm{NaCl}, 0.01 \mathrm{M}$ Tris- $\mathrm{HCl}(\mathrm{pH} 8.0), 0.01 \mathrm{M}$ EDTA, $0.1 \%$ sodium dodecylsulfate at $55^{\circ} \mathrm{C}$ for $1 \mathrm{~h}$ and $37^{\circ} \mathrm{C}$ for $16 \mathrm{~h}$ to disrupt the viral proteins, and then extracted with the same volume of Tris buffersaturated phenol, phenol-chloroform-isoamyl alcohol (25:24:1), and chloroform-isoamyl alcohol (24:1). The DNA from the resultant aqueous layer was precipitated by the additions of 100 and $70 \%$ ethanol, and the pellet was resuspended in Tris-HCl EDTA (TE) buffer.

The viral DNA was digested with restriction endonucleases (EcoRI, BglII, HindIII, BamHI) under the conditions recommended by the manufacturers. The DNA fragments were separated on a $0.7 \%$ agarose gel in Tris-acetate EDTA (TAE) buffer.

Viral susceptibility of surviving cells. In order to characterize the immotile Heterocapsa circularisquama cells surviving viral infection (see 'Results'), 4 cells were randomly picked from the culture lysate using capillary pipettes and were inoculated into fresh SWM3 medium separately. The viral susceptibility of the clonal subisolates thus obtained was tested by adding $5 \%(\mathrm{v} / \mathrm{v})$ aliquots of fresh viral suspension to triplicate of exponentially growing cultures. Cultures were monitored for evidence of lysis by optical microscopic observation and in vivo chlorophyll fluorescence measurement.

Host range. The host range of the isolated virus was tested by adding $5 \%$ (v/v) aliquots of fresh viral suspension to triplicate cultures of the exponentially growing strains listed in Tables 1 \& 2. The cultures were incubated under the same conditions of light and temperature used for growth of each algal culture and monitored for evidence of lysis by optical microscopic observation and in vivo chlorophyll fluorescence measurement. These observations and measurements were compared to control cultures to which aliquots of viral suspension treated at $100^{\circ} \mathrm{C}$ for $15 \mathrm{~min}$ were added. Cultures that were not lysed after $14 \mathrm{~d}$ were considered to be unsuitable hosts for this virus.

\section{RESULTS}

\section{Virus isolation}

Within $7 \mathrm{~d}$ of receiving an inoculum from the natural seawater sample, cell lysis was detected in the Heterocapsa circularisquama HA92-1 culture. The resultant lysate contained numerous small particles stainable with DAPI. In contrast, in the control culture, cell lysis did not occur and the small DAPI-positive particles were not observed.

In Heterocapsa circularisquama HU9433-P cultures to which the clonal pathogen suspension was added, cell lysis occurred approximately $3 \mathrm{~d}$ after the inoculation (Figs. 1A \& 2). Serial transfers from cultures that showed cell lysis into exponentially growing $H$. circularisquama HU9433-P cultures consistently resulted in cell lysis (Fig. 2). Moreover, the pathogen retained algicidal activity after filtration through a $0.2 \mu \mathrm{m}$ pore size filter, although the algicidal response lagged behind that of the non-treated pathogen suspension

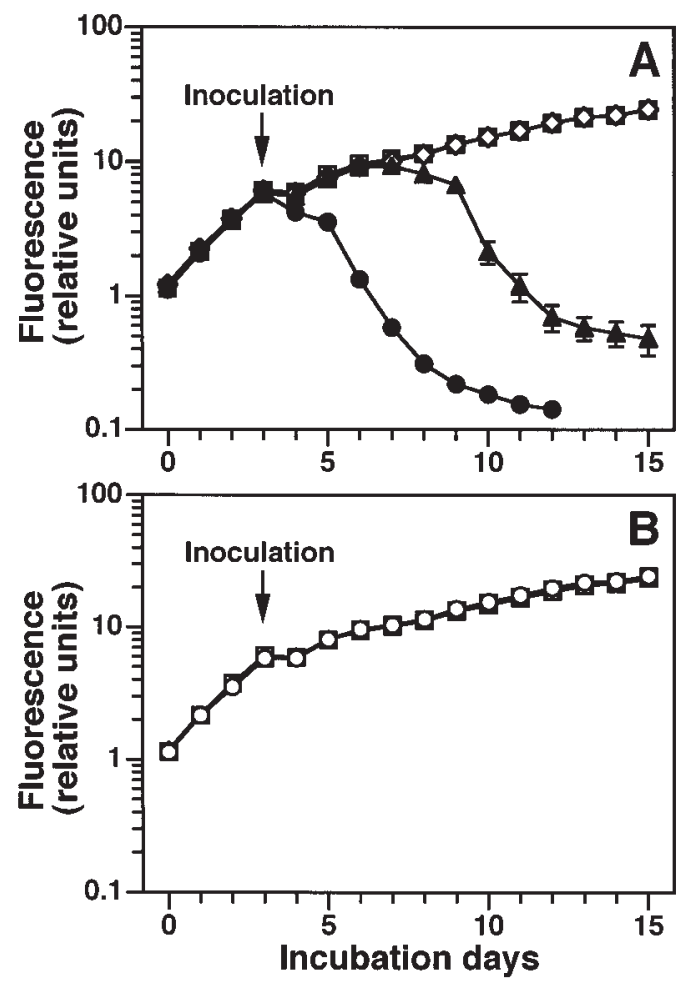

Fig. 1. Growth curves of Heterocapsa circularisquama HU9433-P as measured by in vivo chlorophyll fluorescence, showing the response following additions of the clonal pathogen suspension with (A) no treatment (-), filtered through a $0.2 \mu \mathrm{m}$ pore size filter $(\mathbf{\Lambda})$, a $0.1 \mu \mathrm{m}$ pore size filter $(\diamond)$ and $(\mathrm{B})$ no treatment $(\mathbf{O})$, filtered through a $0.2 \mu \mathrm{m}$ pore size filter $(\Delta)$ with further heat treatment at $100^{\circ} \mathrm{C}$ for $15 \mathrm{~min}$ relative to a no-addition control $(\square)$. Values are mean $\pm \mathrm{SD}$ $(n=3)$. Note that several symbols overlap 


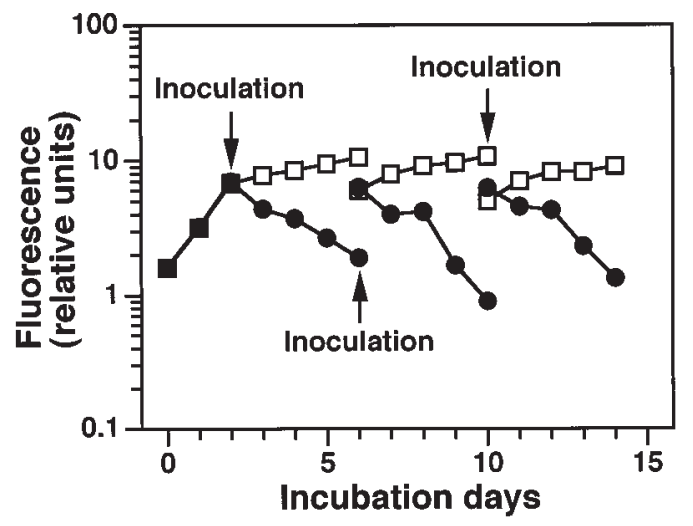

Fig. 2. Growth curves of Heterocapsa circularisquama HU9433-P after serial transfer of lysed cultures $(\bullet)$ relative to a no-addition control $(\square)$. Values are mean \pm SD $(n=3)$

addition, probably because of the decrease in the multiplicity of infection caused by the partial retention of pathogens onto filters (Fig. 1A). In contrast, algicidal activity was lost by filtration through a $0.1 \mu \mathrm{m}$ pore size filter and also by heat treatment at $100^{\circ} \mathrm{C}$ for $15 \mathrm{~min}$ (Fig. 1), indicating that the pathogen is about 0.1 to $0.2 \mu \mathrm{m}$ in size and is heat-labile.

Thin sections of healthy Heterocapsa circularisquama cells in control cultures indicated that the cytoplasmic organization is diagnostic of dinoflagellates (Fig. 3A). In contrast, an electron micrograph of $H$. circularisquama cells inoculated with the pathogen revealed the presence of intracellular virus-like particles (Fig. 3B-E). No trace of these particles was evident in healthy cells in the control cultures. Moreover, particles similar in appearance were observed in culture lysates (Fig. 3F).

These results demonstrated that (1) the algicidal pathogen was transferable to a fresh algal culture, (2) viruslike particles were present in the lysed culture, and (3) virus-like particles were not present in healthy culture, fulfilling Koch's postulates. Therefore, it was concluded that the virus-like particles observed within infected cells and in the culture lysates were the algicidal pathogen, which was both morphologically and physiologically a lytic virus. This virus was then termed HcV03 (Heterocapsa circularisquama Virus type 03) after its host species.

\section{Virus characteristics}

When exponentially growing cultures of Heterocapsa circularisquama HU9433-P (Fig. 4A) were inoculated with $\mathrm{HcV03}$, the infected cells lost mobility and settled to the bottom of the incubation vessel. Thereafter, the settled cells became roundish, and were lysed within 2 to $3 \mathrm{~d}$ after the inoculation, indicating that the HcV03 virus has a latent period of 48 to $72 \mathrm{~h}$ (Figs. 1A \& 4B). However, viral lysis was not complete and some cells survived in the culture lysate. Most of the cells that survived were immotile and lost their theca. These immotile cells recovered to the motile form within several days when isolated and cultured in fresh medium. Their growth rates during the exponential growth phase ranged from 0.69 to $0.72 \mathrm{~d}^{-1}$, and were not significantly different from that of the source strain H. circularisquama HU9433-P (ANOVA; p > 0.2, Table 3). Moreover, the regrowth cultures were also lysed by an addition of HcV03 as well as the source strain (Table 3).

Thin-sectioned cells revealed that $24 \mathrm{~h}$ after inoculation some cells exhibited formation of finely granular viroplasm in the cytoplasm near the nucleus (Fig. 3B). Numerous viral capsids were observed inside the viroplasm. Further disruption of the organelles progressed $48 \mathrm{~h}$ after inoculation (Fig. 3C). The viruses were pentagonal or hexagonal in cross section, suggesting icosahedral symmetry (Fig. 3D), and 180 to $210 \mathrm{~nm}$ $($ mean \pm standard deviation $=197 \pm 8 \mathrm{~nm}, \mathrm{n}=30)$ in diameter (Fig. 3F). They were tailless with a multi-layered capsid and an electron-dense core in the center (Fig. 3E). More than 200 viral particles were counted within a thin section of an infected cell $48 \mathrm{~h}$ after inoculation. Using geometric analysis, the whole cell was estimated to contain over 1300 viral particles.

The viral particles could be stained with the fluorochrome DAPI, which stains double-stranded DNA preferentially (data not shown). The viral DNA was resistant to RNase but was degraded by DNase, and was cleaved by all the restriction endonucleases that were tested (data not shown). These results demonstrated that the viral genome consists of doublestranded DNA.

Table 3. Specific growth rates during exponential growth phase (mean $\pm \mathrm{SD}$ ) and viral susceptibility against HcV03 infection of Heterocapsa circularisquama HU9433-P strain and 4 clonal subisolates. The clonal subisolates were established from the immotile cells of $H$. circularisquama HU9433-P strains surviving viral infection. +: lysed

\begin{tabular}{|lcc|}
\hline $\begin{array}{l}\text { Strain or } \\
\text { subisolates }\end{array}$ & $\begin{array}{c}\text { Growth rate } \\
\left(\mathrm{d}^{-1}\right)\end{array}$ & Susceptibility \\
\hline HU9433-P & $0.715 \pm 0.024$ & + \\
Subisolates & & + \\
1 & $0.705 \pm 0.013$ & + \\
2 & $0.690 \pm 0.021$ & + \\
3 & $0.720 \pm 0.016$ & + \\
4 & $0.703 \pm 0.030$ & + \\
\hline
\end{tabular}



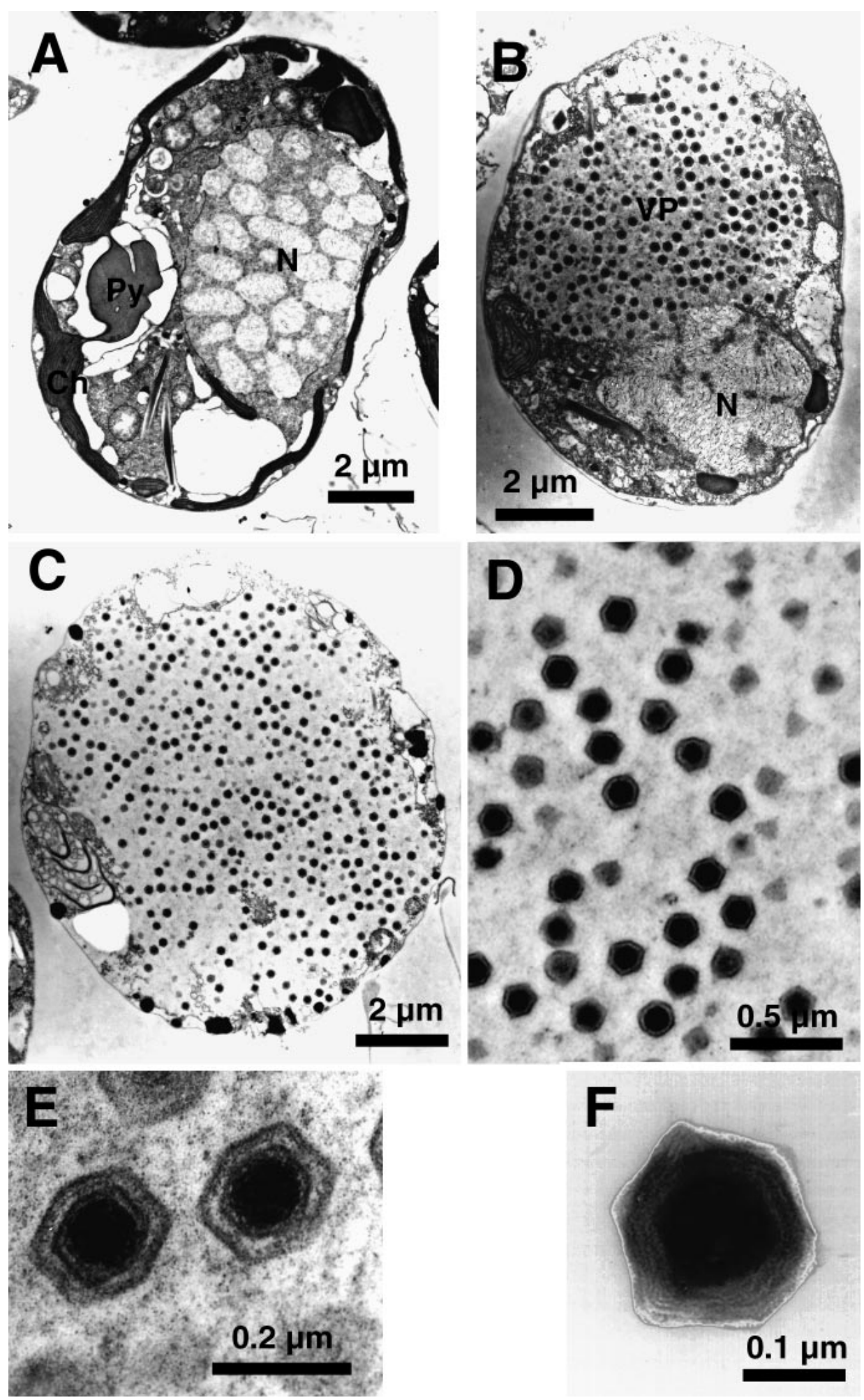

Fig. 3. Transmission electron micrographs of Heterocapsa circularisquama cultures. (A) Thin section of a healthy cell showing the nucleus (N), chloroplasts (Ch) and pyrenoids (Py). (B) Thin section of a cell $24 \mathrm{~h}$ after adding a clonal pathogen showing the development of the viroplasm (VP) in the cytoplasm. (C) Thin section of a cell $48 \mathrm{~h}$ after adding the clonal pathogen. Note that viruslike particles occupied a great part of the thin section. (D, E) Close-up of intracellular virus-like particles. (F) A positively stained virus-like particle that was present in the culture lysate 
Fig. 4. Optical microphotograph of Heterocapsa circularisquama HU9433-P culture (A) before and (B) after HcV03 inoculation. Due to virus inoculation, a high proportion of the cells have been lysed (L) but some cells survived in a roundish and immotile form $(\mathrm{S})$
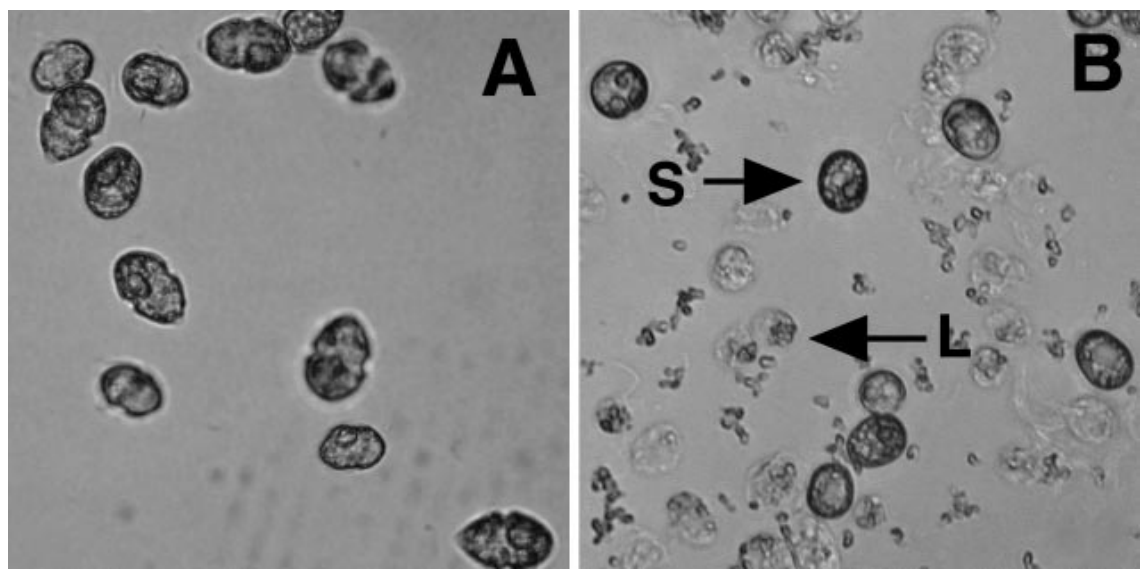

\section{Host range}

The host range of the virus (HcV03) was tested on 25 phytoplankton species, including 18 strains of Heterocapsa circularisquama isolated from various embayments throughout central and western Japan. The virus infected and lysed all $H$. circularisquama strains that were tested (Table 1), but did not cause lysis in any of the other 24 phytoplankton species (Table 2).

\section{DISCUSSION}

This is the first report on the successful isolation and cultivation of a lytic virus infectious to dinoflagellates. Previous ultrastructural investigations of field-collected samples have demonstrated that virus and virus-like particles are intracellular in many phytoplankton species from most major classes (Dodds 1979, Van Etten et al. 1991, Reisser 1993, Zingone 1995, Proctor 1997). However, there are very few reports on the presence of dinoflagellate cells containing viruslike particles (e.g. Blastodinium sp.: Soyer 1978; Gymnodinium uberrimum: Sicko-Goad \& Walker 1979; and Gyrodinium resplenders: Franca 1976). Note that all these species lack a readily visible, multiplate cellulosic wall, the theca (and are hence called athecate dinoflagellates). Zingone (1995) proposed a hypothesis that the cell covering could contribute to reducing the probability of viral infection in thecate dinoflagellates. In contrast, our investigation demonstrates that viruses which infect and cause lysis of thecate dinoflagellates are present in nature, suggesting that the presence of a theca does not necessarily prevent viral infection.

The HcV03 virus has many common characteristics with other isolated viruses infectious to eucaryotic microalgae. Similarities include virus size, morphology, and genome type. This finding indicates that the HcV03 virus belongs to the newly defined family Phy- codnaviridae, which infects unicellular algae (Van Etten et al. 1991). Clearly, further characterizations at molecular levels (e.g. Chen \& Suttle 1996) will be required in order to make a definite decision about its taxonomic position.

On the other hand, there are some significant differences between this virus and other algal viruses. The addition of the virus to an exponentially growing culture of Heterocapsa circularisquama resulted in cell lysis within 2 to $3 \mathrm{~d}$, indicating that the $\mathrm{HcV} 03$ virus has a latent period of 48 to $72 \mathrm{~h}$. Also, the burst size was estimated to be $>1300$ viral particles per lysed cell, based on the geometric analysis of single thin sections from infected cells. Compared with other algal viruses, the latent period and the burst size of this virus are longer and larger, respectively. This could be the result of the large size of the host cells. In addition to the fact that our estimations are only rough ones, however, these parameters may be affected by the growth and physiological condition of the cells (Bratbak et al. 1998), so these differences should be interpreted with care.

A more noteworthy difference is that viral lysis was not complete and some cells survived in a roundish and immotile form despite the fact that this is a clonal strain. One possible explanation for this is the development of resistance to viral infection. Actually, the incidence of resistance has been shown in marine cyanobacteria and eucaryotic phytoplankton (Waterbury \& Valois 1993, Nagasaki \& Yamaguchi 1998, Nagasaki et al. 1999b). However, these immotile cells which survived viral infection recovered to the motile form within several days when isolated and cultured in fresh medium (Table 3). Moreover, the motile cells were infected and lysed by an addition of HcV03 (Table 3). Another possible explanation is derived from the morphological characteristics of the cells that survived, which were immotile and round in shape. Heterocapsa circularisquama often transforms into immotile and roundish forms under unfavorable growth 
conditions (e.g. Uchida et al. 1999). They have been considered to be temporary cysts as described previously for some other dinoflagellates (Pfiester \& Anderson 1987). Although it is unknown how they survived and succeeded in regrowth, these dinoflagellates might have some mechanism to avoid viral infection such as the formation of a thick-layered envelope as is observed in temporary cysts (Nagasaki et al. 2000).

The isolation and cultivation of $\mathrm{HcV}$ demonstrates that viruses which infect and cause lysis of dinoflagellates are a component of natural marine viral communities. Dinoflagellates are among the most important groups of phytoplankton in the sea, especially in coastal waters; they are global in distribution, contain a large number of species, and include various harmful bloom-forming species. Therefore, the host-virus system obtained in this study is expected to be important material for understanding the role of viruses in natural marine environments. Furthermore, HcV has the potential for use as a microbiological agent for eliminating the noxious Heterocapsa circularisquama blooms, because it can be produced in the lab at a relatively low cost, it has been found to be species-specific and is not likely to be harmful to other organisms. In addition, the HcV03 virus originates from natural seawater and has not been genetically manipulated. Intensive studies on this virus from the viewpoint of scale, cost, and safety must of course be assessed in more detail prior to its application to the natural environment.

Acknowledgements. This work was supported by funding from the Fisheries Agency of Japan, the Ministry of Agriculture, Forestry and Fisheries of Japan and the Japan Science and Technology Corporation. We thank Drs T. Uchida (National Research Institute of Fisheries and Environment of Inland Sea), I. Imai (Kyoto University), H. Iwasaki (formerly Mie University), and R. A. Lewin (Scripps Institute of Oceanography) for providing some of the algal cultures used in this work and K. Futashima (Fukuoka Fisheries \& Marine Technology Research Center) for providing the water sample.

\section{LITERATURE CITED}

Brand LE, Guillard RRL, Murphy LS (1981) A method for the rapid and precise determination of acclimated phytoplankton reproduction rates. J Plankton Res 3:193-201

Bratbak G, Egge JK, Heldal M (1993) Viral mortality of the marine alga Emiliania huxleyi (Haptophyceae) and termination of algal blooms. Mar Ecol Prog Ser 93:39-48

Bratbak G, Willson W, Heldal M (1996) Viral control of Emiliania huxleyi blooms? J Mar Syst 9:75-81

Bratbak G, Jacobsen A, Heldal M, Nagasaki K, Thingstad F (1998) Virus production in Phaeocystis pouchetii and its relation to host cell growth and nutrition. Aquat Microb Ecol 16:1-9

Chen F, Suttle CA (1996) Evolutionary relationships among large double-stranded DNA viruses that infect microalgae and other organisms as inferred from DNA polymerase genes. Virology 219:170-178

Chen LCM, Edelstein T, McLachlan J (1969) Bonnemaisonia hamifera Hariot in nature and in culture. J Phycol 5: 211-220

Cottrell MT, Suttle CA (1991) Wide-spread occurrence and clonal variation in viruses which cause lysis of a cosmopolitan eukaryotic marine phytoplankter, Micromonas pusilla. Mar Ecol Prog Ser 78:1-9

Cottrell MT, Suttle CA (1995) Dynamics of a lytic virus infecting the photosynthetic marine picoflagellate Micromonas pusilla. Limnol Oceanogr 40:730-739

Dodds JA (1979) Viruses of marine algae. Experientia 35: $440-442$

Franca S (1976) On the presence of virus-like particles in the dinoflagellate Gyrodinium resplendens (Hulburt). Protistologica 12:425-430

Gastrich MD, Anderson OR, Benmayor SS, Cosper EM (1998) Ultrastructural analysis of viral infection in the brown-tide alga, Aureococcus anophagefferens (Pelagophyceae). Phycologia 37:300-306

Gobler CJ, Hutchins DA, Fisher NS, Cosper EM, SanudoWilhemy SA (1997) Release and bioavailability of C, N, P, $\mathrm{Se}$, and Fe following viral lysis of a marine chrysophyte. Limnol Oceanogr 42:1492-1502

Horiguchi T (1995) Heterocapsa circularisquama sp. nov. (Peridiniales, Dinophyceae), a new marine dinoflagellate causing mass mortality of bivalves in Japan. Phycol Res 43:129-136

Jacobsen A, Bratbak G, Heldal M (1996) Isolation and characterization of a virus infecting Phaeocystis pouchetii (Prymnesiophyceae). J Phycol 32:923-927

Maniatis T, Fritsch EF, Sambrook J (1982) Molecular cloning: a laboratory manual. Cold Spring Harbor Laboratory, Cold Spring Harbor, NY

Matsuyama Y (1999) Harmful effect of dinoflagellate Heterocapsa circularisquama on shellfish aquaculture in Japan. Jpn Agric Res Q 33:283-293

Matsuyama Y, Uchida T, Nagai K, Ishimura M, Nishimura A, Yamaguchi M, Honjo T (1996) Biological and environmental aspects of noxious dinoflagellate red tides by Heterocapsa circularisquama in west Japan. In: Yasumoto T, Oshima Y, Fukuyo Y (eds) Harmful and toxic algal blooms. IOC of UNESCO, Paris, p 247-250

Nagai K, Matsuyama Y, Uchida T, Yamaguchi M, Ishimura M, Nishimura A, Akamatsu S, Honjo T (1996) Toxicity and $\mathrm{LD}_{50}$ levels of the red tide dinoflagellate Heterocapsa circularisquama on juvenile pearl oysters. Aquaculture 144: 149-154

Nagasaki K, Yamaguchi M (1997) Isolation of a virus infectious to the harmful bloom causing microalga Heterosigma akashiwo (Raphidophyceae). Aquat Microb Ecol 13:135-140

Nagasaki K, Yamaguchi M (1998) Intra-species host specificity of $\mathrm{HaV}$ (Heterosigma akashiwo virus) clones. Aquat Microb Ecol 14:109-112

Nagasaki K, Ando M, Itakura S, Imai I, Ishida Y (1994) Viral mortality in the final stage of Heterosigma akashiwo (Raphidophyceae) red tide. J Plankton Res 16:1595-1599

Nagasaki K, Tarutani K, Yamaguchi M (1999a) Growth characteristics of Heterosigma akashiwo virus and its possible use as a microbiological agent for red tide control. Appl Environ Microbiol 65:898-902

Nagasaki K, Tarutani K, Yamaguchi M (1999b) Cluster analysis on algicidal activity of $\mathrm{HaV}$ clones and virus sensitivity of Heterosigma akashiwo (Raphidophyceae). J Plankton Res 21:2219-2226 
Nagasaki K, Yamaguchi M, Imai I (2000) Algicidal activity of a killer bacterium against the harmful red tide dinoflagellate Heterocapsa circularisquama isolated from Ago Bay, Japan. Nippon Suisan Gakkaishi 66:666-673 (in Japanese with English abstract)

Pfiester LA, Anderson DM (1987) Dinoflagellate reproduction. In: Taylor FJR (ed) The biology of dinoflagellates. Blackwell, Oxford, p 611-648

Proctor LM (1997) Advances in the study of marine viruses. Microsc Res Tech 37:136-161

Reisser W (1993) Viruses and virus-like particles of freshwater and marine eukaryotic algae - a review. Arch Protistenkd 143:257-265

Sicko-Goad L, Walker G (1979) Viroplasm and large viruslike particles in the dinoflagellate Gymnodinium uberrimum. Protoplasma 99:203-210

Soyer MO (1978) Particules de type viral et filaments trichocystoides chez les dinoflagelles. Protistologica 14:53-58

Suttle CA (1993) Enumeration and isolation of viruses. In: Kemp PF, Sherr B, Sherr E, Cole JJ (eds) Handbook of methods in aquatic microbial ecology. Lewis Publishers, Boca Raton, p 121-137

Suttle CA, Chan AM (1995) Viruses infecting the marine Prymnesiophyte Chrysochromulina spp.: isolation, preliminary characterization and natural abundance. Mar Ecol Prog Ser 118:275-282

Suttle CA, Chan AM, Cottrell MT (1990) Infection of phytoplankton by viruses and reduction of primary productivity. Nature 347:467-469

Thingstad TF, Lignell R (1997) Theoretical models for the control of bacterial growth rate, abundance, diversity and car-

Editorial responsibility: Gunnar Bratbak,

Bergen, Norway bon demand. Aquat Microb Ecol 13:19-27

Uchida T, Yamaguchi M, Matsuyama Y, Honjo T (1995) The red tide dinoflagellate Heterocapsa sp. kills Gyrodinium instriatum by cell contact. Mar Ecol Prog Ser 118:301-303

Uchida T, Toda S, Matsuyama Y, Yamaguchi M, Kotani Y, Honjo T (1999) Interactions between the red tide dinoflagellates Heterocapsa circularisquama and Gymnodinium mikimotoi in laboratory culture. J Exp Mar Biol Ecol 241: 285-299

Van Etten JL, Lane LC, Meints RH (1991) Viruses and viruslike particles of eukaryotic algae. Microbiol Rev 55: 586-620

Waterbury JB, Valois FW (1993) Resistance to co-occurring phages enables marine Synechococcus communities to coexist with cyanophages abundant in seawater. Appl Environ Microbiol 59:3393-3399

Waters RE, Chan AT (1982) Micromonas pusilla virus: the virus growth cycle and associated physiological events within the host cells; host range mutation. J Gen Virol 63: 199-206

Weinbauer MG, Suttle CA (1997) Comparison of epifluorescence and transmission electron microscopy for counting viruses in natural marine waters. Aquat Microb Ecol 13: 225-232

Yamaguchi M, Itakura S, Nagasaki K, Matsuyama Y, Uchida T, Imai I (1997) Effects of temperature and salinity on the growth of the red tide flagellates Heterocapsa circularisquama (Dinophyceae) and Chattonella verruculosa (Raphidophyceae). J Plankton Res 19:1167-1174

Zingone A (1995) The role of viruses in the dynamics of phytoplankton blooms. Giorn Bot It 129:415-423

Submitted: July 4, 2000; Accepted: October 21, 2000

Proofs received from author(s): December 1, 2000 